\title{
Beyond the Avant-Garde: Benjamin Fondane
} Monique Jutrin

\begin{abstract}
"Ma demeure est hors du camp" 'My dwelling is outside the camp.' In 1917, Benjamin Fondane chose this verse quoting the leper in the Book of Leviticus as an epigraph to his work Psaume du lépreux (Psalm of the Leper); in 1942, he would use it again in a sequence of L'Exode (The Exodus). "Hors du camp," however, Fondane's exclusion was not imposed; rather he claimed it, as he asserted in 1919: "Dans le monde des idées je m'aime lépreux" ("Dialog după actul I") ‘In the world of ideas, I like being a leper.'

If Fondane never joined any literary or political movement, and never subscribed to any philosophical or ideological movement, he nevertheless stayed attentive to that which he saw as innovative. He was better positioned than anyone else to grasp the new values in the visual arts, literature, philosophy, and even science. After all, he was among the first to praise the work of Proust ("L'Art de Marcel Proust"). More than others, he understood the essence of Brancusi's art ("Brancusi"). Nor did he hesitate to wade into the thinking of Lucien Lévy-Bruhl or converse with Gaston Bachelard and Stephane Lupasco. He carried within him his own avant-garde, in the sense that he wanted to be a pathfinder, without, however, seeking to impose his thinking. Indeed, he felt that collective action could only end in failure through its cost to personal freedom.

And yet, can we talk of the Romanian avant-garde without mentioning Benjamin Fondane? Indeed, from an early age in Romania, he was involved with all the vital forces of literature. If he stands out from his contemporaries, it is because his views were penetrating and original.
\end{abstract}

\section{The Insula Venture}

Passionate about the theater, ${ }^{1}$ Fondane defined it as "genul care riscă mai mult" ("Henri Bataille" 253) 'the genre that risks more.' It was a risk that he ran himself. In collaboration with his sister Lina and his brother-in-law Armand Pascal, an actor and director who had worked with Jacques Copeau at the Vieux-Colombier, he founded a theater company that can be considered avant-garde. It was called Insula (The Island), after an avant-garde symbolist review edited by Ion Minelescu.

1 On the question of Fondane's interest for the theater, see "Benjamin Fondane et le théâtre."

Dada/Surrealism No. 20 (2015) 
It was for Insula that Fondane wrote his only manifesto. Contimporanul, another avant-garde journal edited by Ion Vinea, supported his project.

Published in December 1922 in the program for Insula, ${ }^{2}$ Fondane's manifesto deplored the current state of theater: "[S]ervind publicul cu ce-i era mai facil de înţeles şi mai primar, publicul a devenit singurul educator al teatrului" (Manifestul "Insulei" 29) 'In serving an undemanding public, the theater has allowed itself to be shaped by it.' Evoking Ancient Greek theater with some nostalgia, he wrote, “Odinioară .. . [a]rtistul vorbea cu zeii, sau se lupta cu zeii. .. . Astăzi domnul Popescu, inşelat de doamna Popescu cu domnul Ionescu, vine la teatru unde i se oferă în anecdotă, cum un domn Popescu este înşelat de doamna Popescu, cu un domnul Ionescu " 'In the past, the artist talked with gods and struggled against them. . . . Today Mr. Popescu, cuckolded by Mrs. Popescu with Mr. Ionescu, goes to the theater to be fed an anecdote about how a Mr. Popsecu is cuckolded by Mrs. Popescu with a Mr. Ionescu.' The theatre should teach lessons, not of morality, but of taste. Fondane's primary model was Jacques Copeau, whom he quoted in the program: "Pour l'œuvre nouvelle qu' on nous laisse un traiteau nu" 'For new work, may we have a bare stage.'

The first play performed at Insula was Legenda Funigeilor (The Legend of the Spider Silk) by D. Anghel and St. O. Iosif. According to the account provided by actor Claude-Émile Rosen, La Mort de Tintagiles by Maeterlinck and Le Médecin volant by Molière were also performed. Fondane had attempted to produce Les Fourberies de Scapin, but had to abandon the project because of his dissatisfaction with the actors' work during rehearsals. The repertoire listed in the program included plays by Molière, Maeterlinck, Ibsen, and Chekhov, among others. If some of the plays belonged to "classical" theater, their staging and the acting were innovative.

However, this experiment lasted only a short time, from December 1922 to February 1923. In a history of the Romanian theater, Ioan Massoff blames Insula's failure on a cabal (362). Students allegedly disrupted the performances, and the Maison d'art (House of Art) that rented the auditorium to Insula apparently received threats. Massoff doesn't specify the nature of this hostility. However, Paul Daniel asserts that Fondane was forced to close his theater "din cauza dificultăţilor financiare şi a mişcărilor antisemite" (618) "because of financial difficulties and anti-Semitic movements.' This setback was probably one of the factors that led Fondane to leave Romania in December $1923 .^{3}$ As he later wrote in a letter to Liviu Rebrenanu, "S'il avait continué à exister, les racines de mon théâtre m'auraient retenu au pays, et beaucoup de choses auraient été différentes. Mais le destin - mon destin intérieur - en a décidé autrement" (Undated letter) 'If it had continued to exist, my theater's roots would have kept me in the country, and

2 A second program is dated February 1923.

3 In 1923, Romania granted citizenship to Jews, which provoked a new wave of antiSemitism. 
many things would have been different. But destiny - my internal destiny decided otherwise.' Later in Paris, from 1926 to 1930, Fondane followed Artaud's productions at the Théâtre Alfred-Jarry with great interest. He encouraged Artaud to continue his efforts to free theater from the constraints of the text ("Lettre

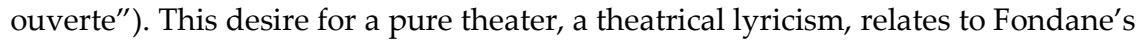
passion for silent film. In an article on Maeterlinck, he describes his vision for a theater without words:

Dar teatrul e fără contur şi fără limită, pentru că sufletul e fără contur şi fără limită . Sunt minute în viaţă în care prăpastia e prea aproape şi ţipătul însuşi ar fi disonant. Omul real pierde gesturile şi logica. Nu poate vorbi. Tace. ("Monna Vanna" 280)

For the theater is without contours or limits because the soul is without contours or limits. In life, there are moments where the abyss is so near that the scream itself is dissonant. Man loses his gestures and his logic. He cannot speak. He goes silent.

\section{Dada and Tzara}

When Fondane arrived in Paris in 1924, surrealism had superseded Dada. Yet, Fondane felt a greater affinity toward Dada and Tzara. He criticized Breton for misunderstanding Dada and creating "une doctrine esthétique qui n'est que celle de dada au second degré" ("Louis Aragon" 40) 'an aesthetic doctrine that is merely that of Dada once removed,' and of doing everything possible to snuff out "la part de l'esprit Dada que le surréalisme charriait dans ses veines" ("Signification de Dada" 77) "the aspects of the Dada spirit that flowed through the veins of surrealism.'

During his first stay in Buenos Aires in 1929, where, invited by Victoria Ocampo, Fondane introduced avant-garde films, which he characterized as "films purs," ${ }^{4}$ he also gave a talk titled "Signification de Dada" (The Significance of Dada). It is important to keep in mind this explosive text defending Dada, whose essence he describes as follows:

Dada était la première manifestation connue de l'esprit, qui se prétendait catastrophique, qui rejetait toute finalité, qui proclamait le scandale pour le scandale, tout en cachant (ou ignorant peut-être) l'idée obscure qui l'y poussait, qui refusait de se laisser prendre pour un Événement, de se laisser ranger soit dans le fait d'art, soit dans les faits spirituels quelconques, et qui, pour la première fois au monde, refusa "le beau

4 Entr'acte by René Char; Un Chien andalou by Louis Buñuel; La Coquille et le clergyman by Germaine Dulac; Le Cabaret épileptique by Henri Gad. This list comes from Fondane in an interview with Sarina Cassvan in Rampa, 12 February 1930. According to a program that has been found, he seems to have introduced L'Étoile de mer by Man Ray as well. 
rôle", prétendait vouloir arriver à l'idiotie pure, et déclarait spontanément que le chef-d'œuvre, et même l'œuvre n'étaient possible sur son terrain. (82)

Dada was the first known manifestation of the spirit to proclaim itself catastrophic, reject all finality, and proclaim scandal for the sake of scandal, while hiding (or perhaps being unaware of) the obscure idea that pushed it there, which refused to be taken for an Event, be pigeonholed either as an artistic or a spiritual act, and which, for the first time ever, refused "the beautiful role," claiming to attain pure idiocy, and declaring spontaneously that the masterpiece and even the work of art were not possible in its realm.

Fondane highlights the essential elements that in his eyes characterized the Dada spirit. First, the element of hasard (chance), a notion that he develops at length later on in "Poésie pure: de Paul Valéry à Tristan Tzara" 5 (Pure Poetry: From Paul Valéry to Tristan Tzara), an article published in Unu on 22 February 1930. In contrast to Valéry's method of "corriger le hasard" 'correcting chance,' writes Fondane, Tzara advocated for "la méthode des mots dans un chapeau" 'the method of pulling words out of a hat.' "Mensonge pour mensonge, lequel préférez-vous? Eh, mais pour ma part, le plus riche; premièrement le sol généreux, ensuite l'intelligence perfectionnée" 'Lie for lie, which do you prefer? For my part, I prefer the richest: first, fertile soil, then intelligence perfected.'

He concludes by asserting that Tzara was no longer [just] the leader of a school or even a dadaist, but rather "un voyant lyrique" 'a lyrical seer.' Coming from Fondane, this is praise indeed. He had, after all, dedicated one of his first poems written in French to Tzara, "Scènes de la vie des lapons" (Scenes from the life of Laplanders). Even if their paths diverged after Tzara joined surrealism, Fondane continued to feel deep respect for Tzara.

Among the traits characterizing Dada, Fondane also names humor, particularly black humor, which he refers to more than once in his writings on film (for example, in "Présentation de films purs"). According to Fondane, humor is the expression of the modern sense of the tragic, the feeling of nothingness in the contemporary human spirit. He reached toward this humor which persists in the face of disaster, and which retreats from neither the absurd nor evil, this humor referred to by some as the "révolte supérieure de l'esprit" 6 'superior revolt of the spirit.' Sole response to the absurd, such humor negates the domain of reality and its evidencies to affirm the freedom of the existent.

5 Dealing with two collections by Tzara, L'Indicateur des chemins du cour and De nos oiseaux.

6 An expression of Léon-Pierre Quint, quoted by Breton in his preface to Anthologie de l'humour noir (Breton 870). 


\section{Breton and Surrealism}

From 1925 to 1928, Fondane worked with Ilarie Voronca as a correspondent for the journal Integral, edited by the painter M. H. Maxy. In outlining Integral's intended profile, Voronca pointed to Tzara in an effort to align their project more closely with Dada and differentiate it from that of surrealism. French contributors to the journal were mainly former dadaists and "dissidents" from the group led by Breton. In a double issue devoted to an anthology of Romanian and French texts, published in June and July 1927, it is Fondane who charts the "tableau des forces vives" 'profile of the vital forces' in contemporary French poetry. Surrealism is represented by Joseph Delteil and Roger Vitrac. Works by Georges RibemontDessaignes, Paul Dermée, Max Jacob, and Pierre Reverdy are also included, as well as a fragment of Tzara's L'Homme approximatif and three poems by Fondane. ${ }^{7}$

It is also in Integral that Fondane first expressed his criticism of Breton's surrealism, focusing on four main points: automatic writing, the use of dreams, the interpretation of Rimbaldian voyance, ${ }^{8}$ and political engagement.

Si le surréalisme fut vraiment - et il ne fut pas autre chose, - le choix délibéré d'un principe premier: l'automatisme psychique pur, suppression de la réalité euclidienne ... au bénéfice du rêve pris en tant qu'activité créatrice, . . . - comment la transformation s'opéra-t-elle en faveur d'une discipline issue d'un malaise matériel . . . d'une métaphysique intéressée . . . et ne visant qu'un but: la dictature du prolétariat. ("La Révolution et les intellectuels" 14)

If surrealism was truly - and nothing but - the deliberate choice of a fundamental principle: pure psychic automatism, the suppression of Euclidian reality ... in favor of dreams taken to be creative activity, ... how did it morph to favor a discipline ... that stems from a material unease ... : self-interested metaphysics, aiming for only one goal: dictatorship of the proletariat.

Fondane would continue to express disappointment in these contemporaries in whom he had placed the most hope: "je leur en veux d'avoir tourné à l'éloquence et à la dictature politique le sentiment que nous avons du miracle" 'I hold against them that they turned our sense of the miraculous into eloquence and political dictatorship,' he writes in Rimbaud le voyou (Rimbaud the Hoodlum) (160). Fondane expresses his thinking most clearly in Faux Traité d'esthétique (False Treatise on Aesthetics) (1938). Chapter 5 is devoted entirely to the question of automatic writing. Whereas Breton claimed to be preserving the irrational by

7 Specifically, "S.O.S., " "À Madame Sonia Delaunay," and "Scènes de la vie des lapons. "

8 This is an allusion to a letter, commonly called "Lettre du Voyant," written by Arthur Rimbaud to a friend on 15 May 1871, in which he described his revolutionary vision for a new poetry and condemned poets who had preceded him. 
forbidding erasures or corrections, Fondane demonstrates that automatic "dictation" plays into the hands of the intellectual act. In his view, the irrational does not precede the rational, but rather follows it. Thus, he argues for a secondary state of inspiration, where the poet expunges his poetry of the residue of rational thought. The poetic act can grasp the real only insofar as it refuses to conceive of itself as knowledge. A Cartesian of the miracle, Breton explores the Unknown with the sole aim of making it knowable. He even explains the dogma of Rimbaldian voyance by interpreting his pronouncements through the sacrosanct principles of scientific objectivity.

In a letter addressed to his friend Claude Sernet, ${ }^{9}$ dated February 1930, Fondane related the story of the fight in the cabaret Maldoror, where he had the opportunity to do battle with Breton personally ("Lettre à Claude Sernet"). At the same time, he informed Sernet of the publication of the pamphlet titled Un Cadavre, in which Breton was denounced by Desnos, Vitrac, Prévert, and other dissidents. The title Cadavre alluded to the January 1924 collective pamphlet signed by Breton, Aragon, Drieu la Rochelle, and others, drubbing Anatole France on the occasion of his funeral. Fondane, who had just arrived in Paris in January 1924, had been indignant about the virulence and poor taste of this pamphlet and had reacted with "Refus d'être jeune" (Refusal to be Young) a text that remained unpublished for a long time afterward:

Si c'est ça la jeunesse, je refuse d'être jeune.

Si c'est ça la pensée, je refuse de penser.

Si c'est ça l'esprit moderne, je lui tourne le dos.

Si c'est ça l'art nouveau, il me fait rire. (29)

If that is youth, I refuse to be young.

If that is thought, I refuse to think.

If that is modern spirit, I turn my back.

If that is new art, I have to laugh.

In 1932, Fondane refused to sign the petition supporting Aragon, who had been indicted for incitement to murder after the publication of his poem "Front rouge." In a letter addressed to the Headquarters of the Surrealist group, Fondane insisted on the cowardice of not assuming responsibility for the possible impact of one's writings. ${ }^{10}$

9 Fondane contributed to Discontinuité, a short-lived journal with only one issue published in 1928, edited by Claude Sernet and Arthur Adamov.

10 For example: “Feu sur Léon Blum / Feu sur Boncour Frossard Déat / Feu sur les ours savants de la social-démocratie / Feu Feu j'entends passer / la mort qui se jette sur Garchery Feu vous dis-je / Sous la conduite du Parti communiste" 'Fire on Léon Blum / Fire on Boncour Frossard Déat / Fire on the trained bears of the social-democracy / Fire Fire I hear pass by / 
Thus, a careful reading of the texts in which Fondane measures himself against surrealism allows us to distill his own expectations, ethical, as well as poetic.

\section{Cinema and Ciné-poems}

Fondane's only texts that could perhaps be characterized as surrealist are his cinépoems titled Trois Scénarii-ciné-poèmes (Three scenarios - ciné-poems), published in 1928 by Documents internationaux de l'esprit nouveau and accompanied by two Man Ray photographs. ${ }^{11}$ Before undertaking poetic work in French, Fondane put himself through a sort of language detoxification process. As he writes in his preface, “C'est qu'une partie de moi-même que la poésie refoulait, pour pouvoir poser ses propres questions, angoissantes, vient de trouver dans le cinéma un haut-parleur à toute épreuve" 'A part of myself that poetry was repressing to be able to pose its own anguishing questions, has just found an unwavering voice in film.' Fondane sees cinema as an appareil à lyrisme (tool for lyricism), since "il accouche de l'arbitraire, introduit le point de vue du discontinu, le jeu du simultané, créant une réalité nouvelle" 'it gives birth to the arbitrary, introduces the point of view of the discontinuous, the play of the simultaneous, creating a new reality.' Double-exposure allows two bodies to occupy the same point in space at the same instant. This preface is titled " $2 \times 2$, , probably alluding to Leon Chestov's struggle against the evidence of reason. Fondane's contact with this existential thinker had a determining impact on his own evolution.

These three unfilmable scenarios, which were written to be read, appear as a succession of sentences or images, each one numbered, creating the impression of a film cutting. Technical directions accompany the texts, for example: doubleexposure, close-up, accelerated motion, unclear focus, dissolve, pan shot, and zoom. These cine-poems, similar to the eye capturing cinematographic images, call for a new way of reading. Barre fixe (High Bar) begins as follows:

1. Un mur sur lequel en toutes lettres: LIBERTÉ ÉGALITÉ FRATERNITÉ

2. Les trois mots jouent sur le mur, le premier en gros caractères les autres dans le flou

3. Les caractères se détachent font des miracles de souplesse pour former des mots mi-intelligibles mi-absurdes

4. Une tête suit attentivement ce ballet

the death which throws itself on Garchery Fire I tell you / Under the guidance of the Communist Party' (Aragon, "Front rouge/The Red Front" 258-59).

11 In his Anthologie du cinéma invisible, Christian Janicot discusses similar experiments conducted at the time. 
L'on peut toutefois, à travers ces images absurdes, distinguer un tracé narratif: un jeune homme tenté par le suicide finit par trouver un emploi dans une compagnie d'assurances, ${ }^{12}$ et épouser la statue de Voltaire.

1. a wall on which is written: LIBERTÉ ÉGALITÉ FRATERNITÉ

2. the three words play on the wall, the first in bold letters, the others unfocused

3. the letters detach from one another, perform miracles of flexibility to form semi-intelligible, semi-absurd words

4. a head follows this ballet attentively

In these absurd images, we can nevertheless discern a narrative thread: a young man tempted by suicide ends up finding work in an insurance company and marries the statue of Voltaire.

In the spring of 1930, Fondane was hired as assistant director and scriptwriter by Paramount Studios in Joinville-le-Pont. His work consisted mainly of remaking screenplays for commercial films. It was thankless work, timing scenes, and numbering them and distributing the plans. In 1933, he escaped this slavery for two months to direct Rapt in Valais (a canton in the Swiss Alps), a film for which he wrote the screenplay and script, based on La Séparation des races by Ramuz. The film was accompanied by music of Arthur Honegger and Arthur Hoérée, and staged by Dimitri Kirsanoff. Dialogue was reduced to a minimum, in favor of a sound montage with Ondes Martenot and diverse sound effects. The film, appreciated by a small number of amateurs, was not well-received by the general public.

In this film, Fondane had attempted to realize his own conception of cinema. In his article "Du Muet au Parlant: Grandeur et décadence du cinéma" (From Silent to Talking: Grandeur and Decadence of the Cinema), written in December 1929 and published in the April 1930 issue (no. 5) of Bifur, Fondane expresses his position on the evolution of the cinema in clear terms. In a perceptive analysis, he deplores the replacement of silent film with talkies. He proposes, as a compromise between silent and talking film, le film sonore (sound film). In his view, film should remain silent but accompanied by superimposed word and sound.

Une nouvelle forme du film serait là, non pas meilleure que l'ancienne, mais différente, ... dont le caractère fondamental ne serait pas le son, mais le silence, plus encore que dans le film muet, le silence dont on aura obtenu, grâce aux contrastes de la parole ou du bruit, un rendement imprévu en profondeur, un silence qui n'aura pas uniquement de la

12 During his early years in Paris, Fondane worked for an insurance company called l'Abeille, where he met Geneviève Tissier, whom he would marry in 1931. 
surface mais bel et bien du volume, avec cette restriction que la parole et le bruit . . . se développeront sur un autre plan ... que celui ... de l'image.... (149-50)

This could mark a new form of film not better than the old one, but different... whose fundamental character would not be sound, but rather silence, even more so than in silent film - a silence obtained by means of contrasts with the spoken word or noise, with unexpected depth, a silence that will have not only surface, but also real volume, provided that word and noise be developed on a plane other than that of the image

Fondane's final cinematographic project was Tararira, ${ }^{13}$ a musical and talking film produced with the Aguilar brothers in Buenos Aires in 1936. Fondane summarized the film, which reflected the dadaist taste for the absurd, in a letter dated 19 May 1936 to his sister Line: "Ce sera la caricature de la société d'aujourd'hui, un monde où l'art n'est plus. Les frères Aguilar, luthistes de talent, ne pourront être engagés pour un concert que parce qu'on les prend pour de célèbres bandits ; ils finiront par mettre en pièces le salon d'une vieille duchesse en jouant sans instruments le Boléro de Ravel" 'It will be a caricature of society today, a world in which art no longer exists. The Aguilar brothers, talented lutists, will be hired to give a concert only because they are taken for famous bandits. In the end, they will smash up the living room of an old duchess while playing Ravel's Bolero without instruments.'

The few who attended a private screening of Tararira in 1937 will always remember the thrill of this last scene. However, Tararira was never distributed, for reasons still unknown. Was it ruined by incompetent editing? Was the producer worried about its edginess? The film reels have never been found. All that remain are some frames and photographs of the filming, which point to a burlesque style inspired by the commedia dell'arte.

During the filming of Tararira, the specter of war haunted Fondane, who feared not being able to return to France. He had hoped to secure other contracts in Argentina and to settle down there if his films enjoyed success, but when the failure of Tararira made this unlikely, Fondane would be trapped by History. ${ }^{14}$

13 Like Tzara's word Dada, this word is colored with a variety of meanings. In Spanish, it is a cry of joy, trembling, a joke. It can be used as an interjection indicating incredulity or disdain, like the French tarare or taratata. In Argentina, it is also the name of a river fish of varying color.

14 For biographical information, see my Benjamin Fondane ou le périple d'Ulysse and Avec Benjamin Fondane au-delà de l'histoire. 


\section{Freedom and Limits}

During the war years, Fondane worked relentlessly on his poetic and philosophical work. Arrested on 7 March 1944 and murdered at Auschwitz on 2 or 3 October, he left an enormous, unfinished body of work. Numerous incomplete or unpublished manuscripts remain.

Among remaining drafts is the outline of a text entitled, "Écrire sur la poésie 33-43" ("Writings on Poetry, '33-'43"), Fondane's attempt to sketch a panorama of that decade in poetry, done at the request of Georges Ribemont-Dessaignes. In this article, Fondane points to Paul Éluard as a triumphant figure, and Tristan Tzara as a forgotten figure. The text focuses on the notion of poetic freedom and takes issue with Jean Paulhan's Les Fleurs de Tarbes. Where Paulhan sees a maladie du language (an illness of the language), Fondane believes there is a maladie de l'esprit (illness of the spirit): “l'idée qu'on se fait de la poésie n'est . . . qu'un prolongement de l'idée qu'on se fait de l'homme.... Paulhan pense que le poète n'est libre que s'il se donne des entraves" (52-53) 'Our idea of poetry is that it is an extension of our idea of man. Paulhan thinks that the poet is only free if he creates constraints for himself.' Fondane concedes the existence of internal and external constraints but refuses the notion that such constraints might constitute freedom.

As early as 1933, Fondane defined poetic language while writing about Roger Vailland's translation of Ulysse dans la cité by Voronca: "des rythmes obscurs, des similitudes savantes, des obstacles invisibles, bref toute une technique obscure qui, pour être libre de toute domesticité, imposée, n'en est pas moins assujet[t]ie à des nécessités internes" ("Ulysse dans la cité" 536) 'abstruse rhythms, learned similitudes, invisible obstacles, in short, a whole obscure technique which, while seeking freedom from any imposed domesticity, still remains subject to internal necessities.'

In the penultimate chapter of Baudelaire et l'expérience du gouffre (Baudelaire and the Experience of the Abyss), Fondane develops his own philosophy of poetic freedom and constraints. He talks of poetic risk, which he terms l'esthétique d'Ulysse, which oscillates between the poles of the trouvaille (the poetic 'find') and acquired skill (360). "Car la trouvaille est, par elle-même, une limite; elle est la frontière d'un univers voulu, qui se sait et se veut 'littéraire' et qui, aussi loin qu'elle aille, ne craint pas moins de quitter la circonférence où elle s'est de bonne foi enfermée" 'For the trouvaille is in itself a limit: it is the edge of a created universe, known to be and considering itself "literary" and, regardless of how far the trouvaille extends, it still refrains from leaving the circumference in which it has enclosed itself in good faith.'

Poetic freedom, as defined by Fondane, is the right and the duty to be what one is. Mallarmé or Rimbaud may have the right to be obscure, but Fondane claims the right to clarity and coherence. For him, poetry is an act - a cry, prayer, song, magic - whatever - an act secreted by man, like sweat or tears. Every act reverberates in the world, amplifying it by its very existence. 
In the existential thinking that he developed during the same period, Fondane pursued his reflections on freedom. In his last philosophical text, "Le Lundi existentiel et le dimanche de l'histoire," Fondane writes: "Si . . une limite est, pour vous, 'une torture et un aiguillon,' . . . si vous étouffez en un monde qui n'a ni portes ni fenêtres ... , alors, seulement, votre passion sera existentielle“ (50) 'If . . . for you, a limit is "a torment, a prod," if you are suffocating in a world without doors or windows, then and only then will your passion be existential.'

Thus, for Fondane, the avant-garde would only ever represent a limit within which he refused to be confined.

Translated from the French by Lynn E. Palermo

\section{Works Cited}

Aragon, Louis. "Front rouge/The Red Front." Trans. E. E. Cummings. A Miscellany Revised. By E. E. Cummings. Ed. George J. Firmage. New York: October House, 1965. 252-73. Print.

"Benjamin Fondane et le théâtre." Cahiers Benjamin Fondane 11 (2008): 5-114. Print.

Breton, André. CEuvres complètes. Ed. Marguerite Bonnet. Vol. 2. Paris : Gallimard, 1992. Print.

Cassvan, Sarina. “Un avangardist român la Paris: De vorbă cu B. Fundoianu.” B. Fundoianu: Strigăt întru eternitate. Ed. Geo Șerban. [Bucharest]: Federația Comunităților Evreiești din România, 1998. 140-44. Print.

Daniel, Paul. “Destinul unui poet." Poezii. By Benjamin Fondane. Ed. Paul Daniel and G. Zarafu. Bucharest: Minerva, 1978. 595-642. Print.

Fondane, Benjamin. Baudelaire et l'expérience du gouffre. Paris: Seghers, 1947. Print.

—. "Brancusi" Les Cahiers de l'étoile 2 (1929): 708-25. Print.

. “Dialog după Actul I.” Rampa 23 Feb. 1919. Imagini şi cărţi. By B. Fundoianu. Ed. Vasile Teodorescu. Bucharest: Minerva, 1980. 274-76. Print.

_. "Du Muet au Parlant: Grandeur et décadence du cinéma." Bifur 5 (April 1930): 149-50. Print.

—. "Écrire sur la poésie 33-43." Cahiers Benjamin Fondane 7 (2004): 52-54 Print.

—. Faux Traité d'esthétique: Essai sur la crise de réalité. 1938. Paris : ParisMéditerranée, 1998. Print.

—. "Henri Bataille" Sburătorul literar 25 March 1922. Imagini şi cărţi. By B. Fundoianu. Ed. Vasile Teodorescu. Bucharest: Minerva, 1980. 252-56. Print.

—. "Lettre à Claude Sernet." Non lieu 2-3 (1978): 88-89. Print. Signed "Mielouchon." 
- "Lettre ouverte à Antonin Artaud sur le Théâtre Alfred Jarry." Europe 667-68 (Nov.-Dec. 1984): 97-93. Print.

. "Louis Aragon ou Le Paysan de Paris." 1927. Fundoianu/Fondane et l'avantgarde. Ed. Petre Răileanu and Michel Carassou. Bucharest: Fondation culturelle roumaine; Paris: Paris-Méditerranée, 1999. 39-43. Print.

—. "Le Lundi existentiel et le dimanche de l'histoire." L'Existence. By Albert Camus et al. Paris: Gallimard, 1945. 25-53. Print.

—. "Manifestul 'Insulei.' Insula. [Bucharest: Cultura Naţională, 1922]. 29-30. Print. December 1922 program.

—. "Monna Vanna." 1920. Imagini şi cărţi. By B. Fundoianu. Ed. Vasile Teodorescu. Bucharest: Minerva, 1980. 279-82. Print.

- "Notes: L'Art de Marcel Proust." Images et livres de France. Trans. Odile Serre. Paris: Paris-Méditerranée, 2002. 139-46. Print.

—. "Poésie pure: De Paul Valéry à Tristan Tzara." Unu 22 (Feb. 1930). Print. . "Présentation de films purs." Écrits pour le cinéma. Ed. Michel Carassou.

Paris: Plasma, 1984. 55-69. Print.

—. "Refus d'être jeune." Fundoianu/Fondane et l'avant-garde. Ed. Petre

Răileanu and Michel Carassou. Bucharest: Fondation culturelle roumaine; Paris: Paris-Méditerranée, 1999. 27-29. Print.

_. "La Révolution des intellectuels." Integral 12 (April 1927): 14-15. Print.

- Rimbaud le voyou. 1933. Paris: Plasma, 1979. Print.

_. "Scènes de la vie des lapons." Integral 13-14 (June-July 1927).

—. "Signification de Dada." Fundoianu/Fondane et l'avant-garde. Ed. Petre

Răileanu and Michel Carassou. Bucharest: Fondation culturelle roumaine; Paris: Paris-Méditerranée, 1999. 76-82. Print.

—. Trois Scénarii: Ciné-poèmes. Paris: Baze, 1928. Print.

—. "Ulysse dans la cité, par Ilarie Voronca." Cahiers du Sud 10 (1933): 535-37. Print.

- Undated letter published in Adam, July 1, 1930. Print.

Integral 13-14 (June-July 1927). (Anthology of French and Romanian texts). Print. Janicot, Christian. Anthologie du cinéma invisible: 100 scénarios pour 100 ans de cinéma. Paris: Jean-Michel Place, 1995. Print.

Jutrin, Monique. Avec Benjamin Fondane au-delà de l'histoire ou les carnets d'Ulysse, 1924-1944. Paris: Parole et Silence, 2011. Print.

Jutrin, Monique. Benjamin Fondane ou le périple d'Ulysse. Paris: Nizet, 1989. Print. Massoff, Ioan. Teatrul românesc. Vol. 5. Bucharest: Minerva, 1974. Print.

Rosen, Claude-Émile. “Un brin de souvenir.” Non lieu 2-3 (1978): 14-19. Print. Voronca, Ilarie. Ulysse dans la cité. Trans. Roger Vailland. Paris: Sagitaire, 1933. Print 